\title{
What's next for the Liberals on health?
}

I t's been more than 50 days since the federal Liberals won a landslide majority government on the promise of "real change." Now Parliament is back in session and "Canadians want their government to do different things, and to do things differently," said Governor General David Johnston in his Dec. 4 speech from the throne.

But when it comes to health reform, policy experts say that many of Prime Minister Justin Trudeau's commitments are still too vague to indicate a major departure from federal (or at least Liberal) business as usual.

"To some extent they have backed themselves in a corner," says Åke Blomqvist, a health economist for the CD Howe Institute. "They have created expectations among Canadians that some dramatic things will happen, but there is hesitation to do something that will incur the hostility of the provinces."

\section{A new health accord}

The speech from the throne, which sets out the government's priorities for the upcoming parliamentary session, included only one health promise: to "begin work" with the provinces and territories to negotiate a new long-term funding agreement to replace the lapsed 2004 Health Accord.

The tentative language makes sense "coming off a period when the role of the federal government in health care has been gradually wound down," says Blomqvist. Given the mixed results of the last \$41-billion accord, which was hampered by federal inability to hold provinces to account for health outcomes, "perhaps the Liberals are cautious of trying to re-establish a more active role."

Colleen Flood, Ottawa University Research Chair in Health Law and Policy, says that vague promises don't inspire confidence that a new accord will include the "carrots and sticks" necessary for change. "Why give the money to the provinces at all unless there's some vision that you're aspiring

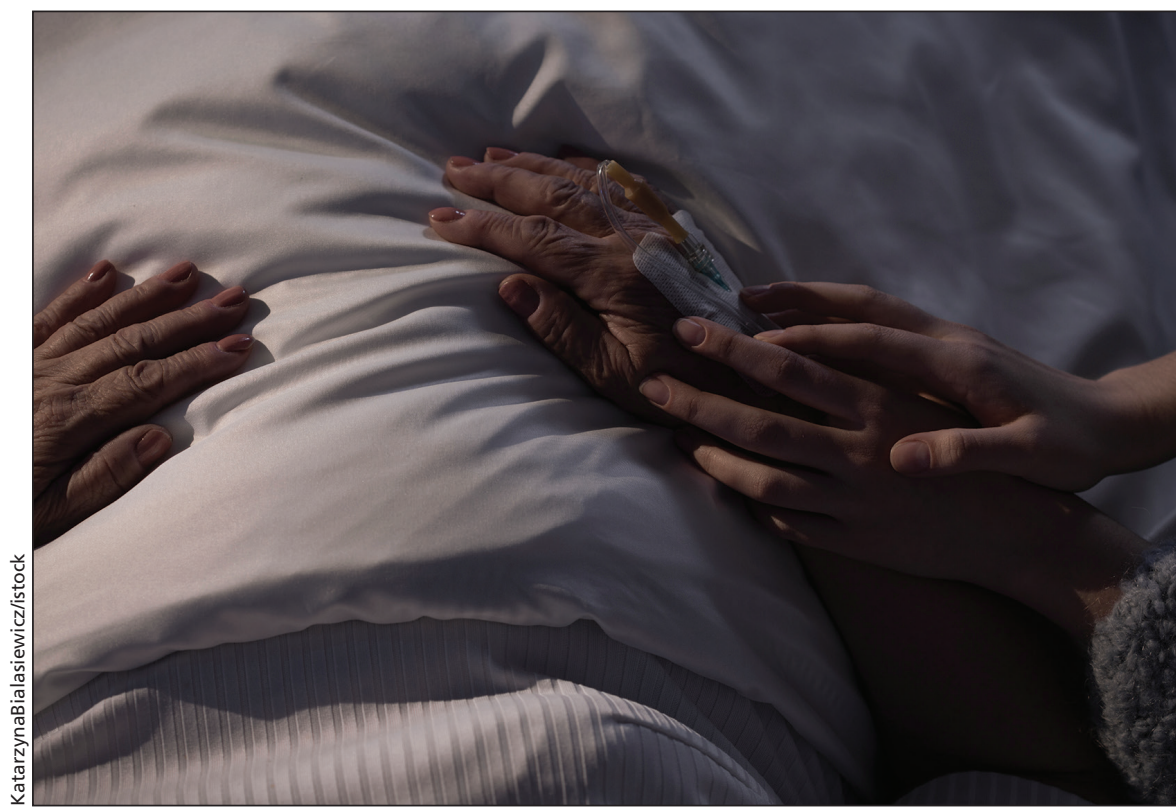

The new Liberal government will have to tackle regulating assisted death and negotiating a health accord in the term ahead.

to? This language is all about the process, having the conversation, and not about the outcome."

The Liberals' promise to invest $\$ 3$ billion over the next four years for more and better home care is a case in point, Flood says. Without defining what "more" or "better" means, "it's the same old, same old," she argues. "The feds commit to put money in before they talk about what they want out."

\section{Pharmacare}

Under the new health accord, the Liberals have promised to join with the provinces to buy prescription drugs in bulk and explore the need for a national formulary. Canada pays some of the highest drug prices worldwide, yet Canadians have relatively poor access to medicines and often can't afford to fill prescriptions under the current patchwork of public and private drug plans.

Although bulk purchasing can achieve "some savings," Flood says the Liberals' plan essentially maintains the status quo. The provinces already cooperate to buy drugs in bulk, but those efforts only cut costs by $1.5 \%$ in 2014 . "The real savings will come when you're buying for the entire country, not just the people under public plans," says Flood.

The College of Family Physicians of Canada and, in an open letter, more than 300 health professionals and academics, are now urging the Liberals to establish a universal pharmacare plan. A national public system like those currently in place to purchase vaccines and blood supply products "would achieve equity of access goals while saving Canadians between $\$ 4$ billion and $\$ 11$ billion per year," stated experts including 11 Canada Research Chairs and 10 recipients of the Order of Canada in the open letter.

Stronger federal leadership on drug reform makes "eminent sense," even to more conservative economists, says Blomqvist. Short of establishing universal pharmacare, there are still "interesting lessons to be learned from European models, where government agencies purchase and supply medicines not only to federal and provincial programs, but to private insurers as well." 


\section{Assisted death and marijuana}

The legalization and regulation of physician-assisted death and recreational marijuana also loom large on Trudeau's reform agenda, although he only cited the latter as a top priority in marching orders to Health Minister Dr. Jane Philpott.

According to Philpott, work is already underway to create a federalprovincial-territorial task force to design a new regulatory framework for marijuana akin to those for tobacco and alcohol, including harsher punishments for providing the drug to children and driving while high.

Meanwhile, Justice Minister Jody Wilson-Raybould has asked the Supreme Court of Canada to extend the ban on assisted death another six months to give the government time to develop a response. The court found the prohibition unconstitutional and gave Parliament until Feb. 6, 2016, to create new legislation. This leaves little time for a new all-party special committee to discuss the issue before breaking for the holidays until late January.

\section{Health promotion}

Most other Liberal health commitments fall into traditional spheres of federal jurisdiction. Promised health promotion initiatives include restricting the advertising of unhealthy foods to children, introducing regulations to ban trans fats and reduce salt in processed foods, updating food labels to include more information on added sugars and artificial dyes, requiring plain packaging for tobacco products and investing \$15 million to create national strategies on vaccination and concussion treatment.

As a general statement of the new government's commitment to its role in public health, these initiatives represent a "sea change" from the past decade, says Bill Jeffery, national coordinator for the Centre for Science in the Public Interest. "There is a bit of ambiguity in the language ... but the details will be very important."

It's unclear how some commitments will differ from work already started by the former Conservative government. For example, "one could read the commitments about nutrition labeling as meaning exactly what the Conservatives proposed, which I thought was a very expensive waste of time," says Jeffery. Others initiatives, like restrictions on junk food advertising, may not be legally sustainable, he adds.

\section{Indigenous health}

Even more ambitious is the Liberals' new promise to implement all 94 recommendations of the Truth and Reconciliation Commission, which includes establishing measurable goals to identify and close the gaps in Indigenous health outcomes, providing sustainable funding for existing and new Aboriginal healing centres and integrating Aboriginal healing practices into the Canadian health care system.

"These are supportive things for Aboriginal health," says Flood, "but without money and a timeline, it's just more smoke."
Foreign aid and refugee health

The Liberals' commitments on foreign aid and refugee health are also a mixed bag. Experts welcome the government's speedy restoration of both basic and supplemental health benefits to incoming refugees. But they're more cynical about Trudeau's promise to refocus foreign aid on "poverty reduction" something already required by law.

"That is not as clear as it sounds, since parties can disagree on the best way to reduce poverty," says Stephen Brown, a political science professor at the University of Ottawa. "For instance, is it by promoting the extractive industry [operations that remove metals, minerals and aggregates from the earth], arguing that it creates jobs ... or is it by focusing on grassroots development projects?"

It's also unclear whether new money for refugee resettlement and mitigating climate change in developing countries will come from an already reduced aid budget. "The Harper government cut spending by about $\$ 1$ billion per year in the past couple of years," Brown explains. "As far as I'm aware, the Liberals have not made any commitments to increase the overall budget."

More details on the Liberal health agenda are expected in January, following a meeting of federal, provincial and territorial health ministers in Vancouver. - Lauren Vogel, CMAJ

CMAJ 2016. DOI:10.1503/cmaj.109-5209 